Transportation Research Forum

Book Review: Driving Questions: Developing a National Transportation Vision

Book Author(s): Joseph M. Giglio

Review Author(s): Joshua Schank

Source: Journal of the Transportation Research Forum, Vol. 49, No. 1 (Spring 2010), pp. 115-116

Published by: Transportation Research Forum

Stable URL: http://www.trforum.org/journal

The Transportation Research Forum, founded in 1958, is an independent, nonprofit organization of transportation professionals who conduct, use, and benefit from research. Its purpose is to provide an impartial meeting ground for carriers, shippers, government officials, consultants, university researchers, suppliers, and others seeking exchange of information and ideas related to both passenger and freight transportation. More information on the Transportation Research Forum can be found on the Web at www.trforum.org. 
Giglio, Joseph M. Driving Questions: Developing a National Transportation Vision. Washington, D.C.: Hudson Institute, 2007. ISBN 155813154X.

\title{
Driving Questions
}

\author{
by Joshua Schank
}

Despite the multiple scathing criticisms of current policy abounding in his book Driving Questions: Developing a National Transportation System, I think it is fair to conclude from reading the book that Mr. Giglio is an optimist. He seems to hold out hope that perhaps U.S. surface transportation policy, which by all accounts is falling far short of achieving what the country needs from it, can be fixed if we start asking the right questions. Consistent with his chosen title, the author raises many important questions throughout the book about surface transportation policy and how we can think about it strategically. Unfortunately, I am not convinced that raising questions on this issue is particularly helpful at this juncture.

Much of the reason for this is not Mr. Gigilio's fault so much as it is the timing of the book, which has been out for some time now. The author prepared the book as an expansion of his testimony to the National Surface Transportation Policy and Revenue Study Commission. That Commission issued its report in early 2008, and that report was the first and loudest voice seeking to answer most of the questions raised in this book. It was followed by reports from the outgoing U.S. DOT Secretary, the Brookings Institution, the National Finance Commission, T4 America, the U.S. Chamber of Commerce, the Bipartisan Policy Center and others, all addressing similar questions. Chairman Jim Oberstar of the House Transportation and Infrastructure Committee released a bill that he considered a blueprint for reform of the nation's surface transportation system. And a new President was elected and installed new management at U.S. DOT which has indicated they intend to weigh in on the future of the program as well by writing their own bill.

In other words, what might not have been crowded space when this book was written has become very crowded indeed. And for those of us who work on this issue on a regular basis, very little of what is in Driving Questions is new. It emphatically and dramatically covers much ground that has already been taken for granted by most writers in the field. For example, the concept that there are modal silos preventing good systemic transportation integration is not a new one at this point. Instead it is an issue that needs to be addressed and doing so is quite challenging. In that sense, I found very little that was new in this book while reading it in 2010. I would bet that this would not have been the case had I read the book when it was first released in 2007.

That said, I am betting that people like me who work on this issue daily are not the intended audience for this book. My sense from reading the book is that the author is attempting to bring this issue to those who have not typically been involved in the discussion. By using plentiful analogies, including numerous references to military history, it is possible that the author is able to communicate the fundamental problems and the outlines of solutions to our surface transportation problems in a way that is easier for the layperson to understand. If the intended audience is an executive or policy-maker without much experience or understanding of transportation policy, the book may succeed in communicating to that audience. In fact it is possible that Mr. Giglio's colloquial style may be more effective in some cases at communicating these points to this audience than the numerous reports referenced above, and in this context it is a useful book.

In sum, while the major issues surrounding surface transportation have largely eclipsed what is covered in this book, I still recommend the book as an introduction to national transportation policy for those unfamiliar with the subject matter. My only hesitation is that while the book is true to its title in posing questions, it is short on providing answers. The answers to these large policy questions are incredibly complicated, requiring not only an intimate knowledge of the subject matter and policy landscape, but an insider's understanding of the art of the possible. Because the book 


\section{Driving Questions}

only scratches the surface of the answers to these complex issues, it may not be all that helpful to decision-makers. However, it is certainly a fun and interesting read for those new to the subject matter who would like to get more involved.

Joshua Schank is director of transportation research at the Bipartisan Policy Center, Washington, DC. He previously worked as a consultant with Parsons Brinkerhoff and as the transportation policy advisor to then Senator Hillary Clinton, working on the most recent reauthorization of the surface transportation bill (SAFETEA-LU). He has also worked as an analyst at the U.S. Department of Transportation Office of the Inspector General and as a transportation planner at the Metropolitan Transportation Authority in New York City. He has served as president of the Washington, DC Chapter of the Transportation Research Forum, and is now a member-at-large of the National Council. Schank has a Ph.D. in urban planning from Columbia University, a master of city planning from the Massachusetts Institute of Technology, and a B.A. in urban studies from Columbia University. He has published numerous articles on transportation policy and planning, and his first book, All Roads Lead to Congress: The \$300 Billion Fight over Highway Funding, was published in October 2007. 